\title{
IMPACT OF COMMERCIALIZATION IN RICE SEED PRODUCTION ON CROP PRODUCTIVITY AND HOUSEHOLD INCOME
}

\author{
H. K. Panta \\ Institute of Agriculture and Animal Sciences, Tribhuvan University, Nepal
}

\begin{abstract}
To assess the impact of commercial rice seed production on rice productivity and household income, a survey study was conducted in Gorkha, Lamjung and Tanahun districts of Nepal covering eight seed production groups. Analyses include probit regression and cost and returns from seed production. Results of the probit model showed that agricultural training, increase in household income, average age of household head, use of modern rice cultivars, household size, and involvement of women in agricultural decision making have significant positive effect on adoption of the modern rice seed production technology. Similarly, significant difference between non-adopters and adaptors was observed in relation to seed productivity. Study showed that yield of improved seed technologies are higher by 2 ton/ha than the traditional rice varieties and net income is around NRs 43,500 per hectare. Study also showed that the improved rice seed technologies, amount of seed applied, area planted, and fertilizer applied are highly significant variables affecting rice productivity.
\end{abstract}

Keywords: commercialization, technology adoption, community based seed production, logit regression, crop productivity

\section{INTRODUCTION}

Agriculture is the major source of food, income and employment for majority of people in Nepal. Agriculture sector provides employment to two-third of total population and contributes onethird in the GDP (MOAD, 2014). In spite of being agricultural country, majority of people living in remote hilly and mountainous regions of Nepal experiences food insufficiency in almost every year. Unavailability of good quality seed results into poor crop harvest. Lack of irrigation, unavailability of modern agricultural inputs, poor market access and lack of modern agricultural technology are the key problems of agricultural sector in Nepal. Climate change has also aggravates the situation of food insufficiency.

Seed is the basic and probably the least expensive input for increasing crop production among production inputs. Good seed is the foundation for sustained rice production, and livelihoods. The use of quality seed can increase crop yield up to 25\% (DISSPRO, 1999). Manzanilla and Johnson (2012) also reported that farmers in mid-hill of Nepal were able to increase rice yield by $40 \%$ when they use improved seed. Seed system in Nepal in basically informal where farmer-to-farmer seed exchange in important mode of seed spread. The formal system supplied only $10 \%$ of total seed demand of the country. Most of the small farmers primarily keep seeds from previous years' own production. There is no formal quality control system but their own traditional selection and post harvest handling practices are employed, where only individual selection process and handling skills are involved.

Unavailability of quality seed of preferred variety is the major production problem for rice in Nepal. Informal seed systems in the country like community based seed producer groups and/or cooperatives provide easy access to preferred varieties, particularly in areas not reached by formal seed systems. 
The average seed replacement rate (SRR) of rice crop at present in Nepal is only about $8.7 \%$ which is far below the recommendation made for self pollinated crops i.e. $25 \%$ (SQCC, 2012). Low SRR means that farmers have been using the older seeds repeatedly year after year resulting into low rice productivity. Different organizations like Department of Agriculture (DOA), Nepal Agriculture Research Council (NARC), National Seed Company (NSC), community based seed production program (CBSP), seed cooperatives/groups, agro-vets, different NGOs and INGOs are involved in seed production and distribution in Nepal at present (CDD, 2011). SQCC (2012) reported that out of total annual seed supply in the country, the share of National Seed Company is only $17 \%$ and the rest is supplied by farmers' groups and cooperatives, development projects and agro-vets.

The seed production programs in western hill region are conducted through community based seed production groups. This system is getting popularity in the region. The participatory varietal selection, training on modern seed production technology, supply of source seed, regular field supervision, seed storage and distribution are the activities adopted by seed producers' groups in the area.

\section{Objectives:}

Assessing impact of commercial rice seed production on rice productivity and household income is the general objective of the study. The specific objectives are:

1. To identify the determinants of adoption of modern rice seed production technology by the seed growers,

2. To study the role of community based seed production system on seed security in the study area, and

3. To study the contribution of seed groups on technology dissemination and adoption.

\section{Study area}

\section{METHODOLOGY}

The study was conducted in Lamjung, Tanahun and Gorkha districts of western Nepal representing mid-hill region of the country. Sundarbazar, Purkot and Palungtar VDCs of Lamjung, Gorkha and Tanahun districts respectively are selected for the purpose of study.

\section{Sampling procedure, sample size, and data collection and analysis techniques}

A random sample of 100 community based seed group members from selected VDCs is selected for survey. The farmers were interviewed personally by using structured questionnaire to elicit the required information. Household survey was conducted from February to April 2014 for the cropping season of 2013. Secondary data were collected from district as well as national level organizations.

Both qualitative and quantitative analyses were used in the study. Quantitative analysis includes Logit regression and costs and returns analyses. Logit model was used to study the factors affecting households decision on adoption of modern rice varieties. Descriptive analysis was used to analyze demographic and farm characterization data. The impact of adoption of modern rice varieties on household income and yield were estimated by costs and returns analysis. The logistic regression model used and the variables measured are as follows:

$$
\mathrm{Y}_{\mathrm{i}}(\mathrm{Adopt}=1)=\alpha_{0}+\alpha_{1} \cdot \mathrm{X}_{1}+\alpha_{2} \cdot \mathrm{X}_{2}+\alpha_{3} \mathrm{X}_{3}+\alpha_{4} \cdot \mathrm{X}_{4}+\alpha_{5} \cdot \mathrm{X}_{5}+\ldots \ldots \ldots \ldots \ldots+\mathrm{e}_{\mathrm{i}}
$$


Where,

$\alpha_{0=}$ a constant term

$\mathrm{X}_{1,} \mathrm{X}_{2}, \mathrm{X}_{3}, \mathrm{X}_{4, \ldots \ldots \ldots}$ are independent variables

Table: Description of variables used in logistic model

\begin{tabular}{|c|c|c|c|}
\hline Variable & Type & $\begin{array}{l}\text { Expected } \\
\text { sign }\end{array}$ & Measurement \\
\hline \multicolumn{4}{|l|}{ Dependent variable } \\
\hline Yi & Dummy & & 1 if farmer is involved, otherwise 0 \\
\hline \multicolumn{4}{|l|}{ Explanatory variables } \\
\hline Gender & Dummy & $+/-$ & 1 if household head is male, otherwise 0 \\
\hline Age of household head & Continuous & - & Age of the household head (years) \\
\hline Ethnicity & Dummy & $+/-$ & 1 if ethnicity is bhramin/chhetri, otherwise 0 \\
\hline Religion & Dummy & $+/-$ & 1 if religion is hindu, otherwise 0 \\
\hline $\begin{array}{l}\text { Education of household } \\
\text { head }\end{array}$ & Continuous & $+/-$ & Years of formal education (schooling) \\
\hline $\begin{array}{l}\text { Primary occupation of } \\
\text { household head }\end{array}$ & Dummy & + & 1 if primary occupation is agriculture, otherwise 0 \\
\hline $\begin{array}{l}\text { Farming experience of } \\
\text { household head }\end{array}$ & Continuous & $+/-$ & Years of experience \\
\hline Active members & Continuous & + & $\begin{array}{l}\text { Number of active (aged 15-60 yrs) members in the } \\
\text { family (persons) }\end{array}$ \\
\hline Family labour size & Dummy & + & $\begin{array}{l}\text { Number of family members working on the family } \\
\text { farm }\end{array}$ \\
\hline Farm size & Continuous & $+/-$ & Area under cultivation (ha) \\
\hline Household income & Continuous & $+/-$ & $\begin{array}{l}\text { Money income earned by the family members } \\
\text { ('000 NRs) }\end{array}$ \\
\hline $\begin{array}{l}\text { Households' access to } \\
\text { credit }\end{array}$ & Dummy & $+/-$ & $\begin{array}{l}1 \text { if at least } 1 \text { family member has access, otherwise } \\
0\end{array}$ \\
\hline $\begin{array}{l}\text { Households' access to } \\
\text { market }\end{array}$ & Dummy & + & 1 if household has access to sell MAPs, otherwise 0 \\
\hline $\begin{array}{l}\text { Households' knowledge on } \\
\text { government policy }\end{array}$ & Dummy & + & $\begin{array}{l}1 \text { if at least } 1 \text { family member is aware of } \\
\text { government policy, otherwise } 0\end{array}$ \\
\hline $\begin{array}{l}\text { Perception on modern } \\
\text { variety }\end{array}$ & Dummy & + & $\begin{array}{l}1 \text { if household head perceives that MV are good to } \\
\text { them, otherwise } 0\end{array}$ \\
\hline $\begin{array}{l}\text { Participation in public } \\
\text { organization }\end{array}$ & Dummy & + & $\begin{array}{l}1 \text { if at least } 1 \text { family member has participated, } \\
\text { otherwise } 0\end{array}$ \\
\hline Attainment of training & Dummy & + & $\begin{array}{l}1 \text { if at least } 1 \text { family member has attended training } \\
\text { on conservation, otherwise } 0\end{array}$ \\
\hline
\end{tabular}

Impact of modern variety was measured through with and without approach where with refers to group and/or cooperative members while the without refers to non-members. The study is the comparison between adaptors and non-adaptors which in this case are members and non-members. 


\section{RESULTS AND DISCUSSION}

\section{General household characteristics}

There was wide diversity of ethnicity in the study area. Brahmin and Chhetri were the dominating casts in study villages contributing 64 percent of the total households. Janajati and Dalit shared 27 and 9 percent respectively to total population. In totality, 66 percent of the respondents were female. Since, females are involved more in farming; they are more informed and thus selected as the respondents. Average age and average number of years of education of the respondent were found 44 and 4 respectively. Regarding the gender composition, 52 of study population was female which is almost reflecting the national scenario.

About 52 percent of the population in the study area was economically active (age between 16 and 50). Agriculture is the primary source of occupation for 42 percent of the study population. The composition of business and services were only two and six percent respectively. Foreign employment was the important source of employment, employing nine percent of population in the study area.

Table 10: General household characteristics of the study area

\begin{tabular}{|c|c|c|c|}
\hline \multicolumn{2}{|l|}{ Particulars } & \multirow{2}{*}{$\begin{array}{r}\text { Number } \\
100 \\
\end{array}$} & \multirow[t]{2}{*}{ Percentage } \\
\hline Total no. of HH & & & \\
\hline \multirow{4}{*}{$\begin{array}{l}\text { Ethnicity (no. of } \\
\mathrm{HH} \text { ) }\end{array}$} & Brahmin-Chhetri & 64 & 64 \\
\hline & Dalit & 9 & 9 \\
\hline & Janjati & 27 & 27 \\
\hline & Total & 100 & 100 \\
\hline \multirow{3}{*}{$\begin{array}{l}\text { No. of respondent } \\
\text { by gender }\end{array}$} & Female & 66 & 66 \\
\hline & Male & 34 & 34 \\
\hline & Total & 100 & 100 \\
\hline Household size & & 6 & \\
\hline \multicolumn{2}{|c|}{ Av. Age of the respondent (years) } & 44 & \\
\hline \multicolumn{2}{|c|}{ Av. No. of years of education of the respondent } & 4 & \\
\hline \multirow{3}{*}{$\begin{array}{l}\text { Household } \\
\text { composition (no. } \\
\text { of HH members) }\end{array}$} & Female & 307 & 52 \\
\hline & Male & 288 & 48 \\
\hline & Total & 595 & 100 \\
\hline \multicolumn{2}{|c|}{ Average years of education of adult members (Age $>=16)$} & 6 & \\
\hline \multicolumn{2}{|c|}{ Economically active family members } & 312 & 52 \\
\hline \multirow{8}{*}{$\begin{array}{l}\text { Primary } \\
\text { occupation }\end{array}$} & Agriculture & 250 & 42 \\
\hline & Business & 12 & 2 \\
\hline & Foreign employment & 51 & 9 \\
\hline & Private job & 2 & 0 \\
\hline & Service & 33 & 6 \\
\hline & Student & 203 & 34 \\
\hline & Underage & 44 & 7 \\
\hline & Total & 595 & 100 \\
\hline
\end{tabular}

\section{Land holding}

The total of holding of all selected household was estimated to be 61.79 ha. The average size of holding was 0.62 hectare per household. The average number of parcel was three and the average size of parcel was 0.2 ha per household. Total area by land type in study villages is presented in 
Figure 1. Among the selected households, total lowland area was more than the upland. The composition of lowland and upland in the study area was 55 (34.09 ha) and 45 (27.70 ha) percent respectively.

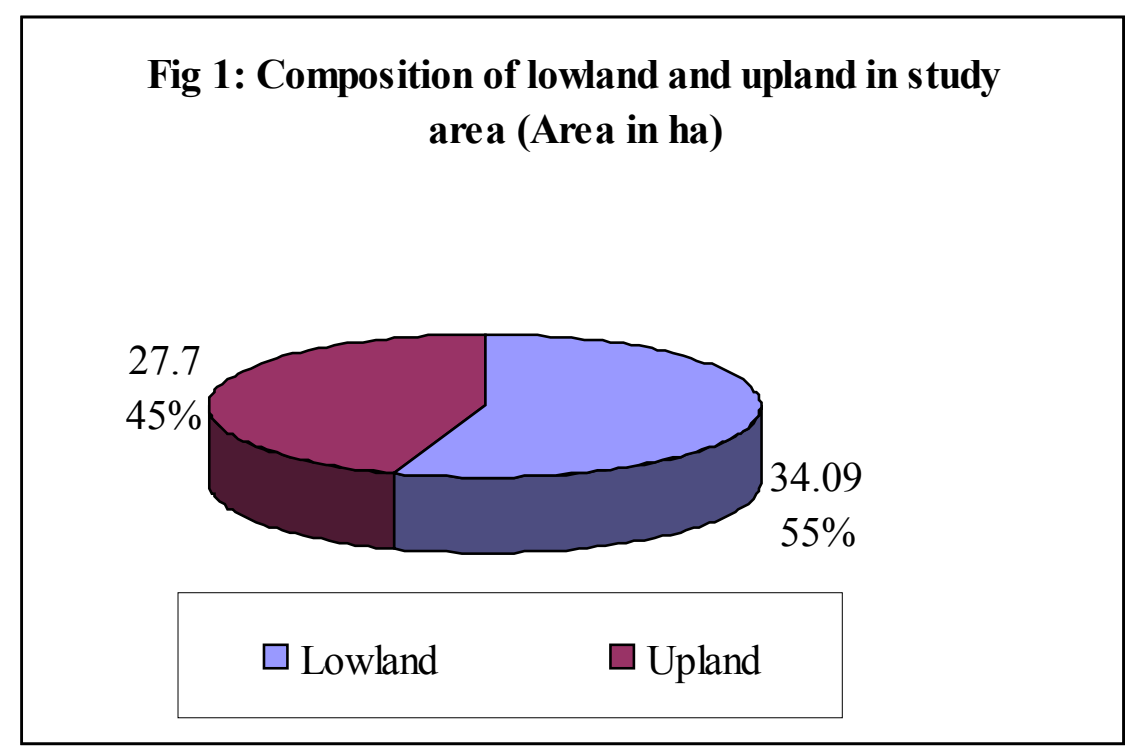

Regarding the distribution of holding, almost 68 percent of selected household possessed the land between 0.1 to 0.4 hectare. Six households possessed less than 0.1 hectare and only one among the selected households possessed more than one hectare. None of them had more than two hectares of land area. Households with 0.4-0.7 and 0.7-1.0 hectare were 21 and 4 respectively. It indicated that almost all of the selected farmers in the study area were small farmers. The distribution of holding in study area is presented in following bar diagram.

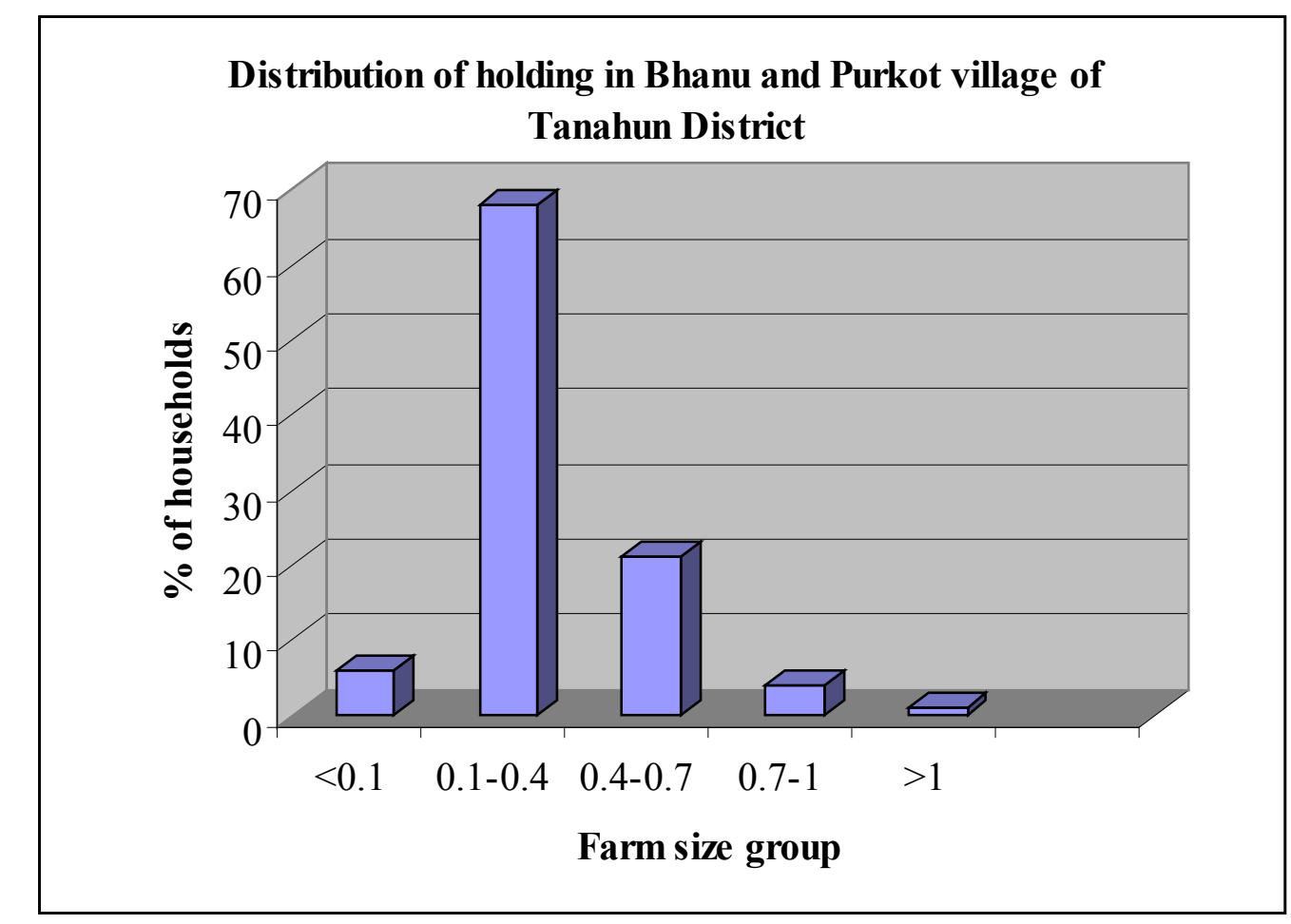


Important soil types in the study area are presented in Table 11. Clayey soil was the most dominating soil type followed by sandy and silty in the study area. Clayey soil constituted almost 40 percent of total holding. Similarly, sandy soil constituted 26 percent, silty 20 percent and the loamy 13 percent of total area in the study area. Sandy soil is common in river basin of foot hills in Nepal.

\section{Effect of seed production on crop productivity and income}

Study showed that if the farmers adopt the modern rice varieties this will result to 1.6 metric ton yield increase. Farmers were directly asked to assess their standard of living before and after adoption of stress tolerant varieties. Significant different on standard of living was observed between adaptors and non-adaptors after adoption which was insignificant after adoption. Income of CBSP farmers on an average was increased by NRs. 10,020 per annum. The increased income was mainly used for children's education (35\%), food (28\%) and farm expenses (20\%).

\section{Effect of seed production on seed security and food security}

Insignificant difference has been observed between members and non-members in terms of seed security. Majority of farmers $(81 \%)$ reported that they rarely consume there seed stock regardless of variety they grow and the environment (favorable or unfavorable). However, almost all respondents stated that their dependency on imported seed has been drastically reduced. About 55 percent of household reported that their access to food have increased after involvement in commercial seed production. However, difference in food consumption between adaptors and non-adaptors was found statistically insignificant. The food availability was increased for additional two months.

\section{Desirable and undesirable traits of modern stress tolerant rice varieties}

Important advantages of MV adoption as stated by farmers are high yield (59\%), tolerant to climatic stress (55\%) and shorter duration (25\%). The disadvantages are short straw (92\%), needs more fertilizer (70\%), poor eating quality (70\%) and early appetizing (32\%). It indicated that farmers generally prefer rice varieties that have high yield, good eating quality, short duration and drought tolerant. Regarding the factors affecting MV adoption includes timely availability of inputs (30\%), irrigation facility (15\%) quality of seed (13\%) and training on scientific management practices (9\%). Regarding undesirable traits, farmers in the study area noticed the rice varieties that have low yield $(62 \%)$, poor eating quality (35\%), susceptibility to pest and diseases $(29 \%)$, and short straw (11\%).

\section{Factors influencing adoption of modern rice varieties}

A logistic model was used to predict factors affecting adoption of improved rice technology. Attendance to agricultural trainings by the household head, household income, average age of household head, use of modern varieties, household size, involvement of women in agricultural decision-making have significant positive effect on adoption of modern rice technologies. Independent variable age in the study is found highly significant. It indicates that more the farmers are experienced greater the chance of adopting modern technology. However, many researches show 
inverse relationship between adoption and age of household head. As use of modern variety indicates farmers' positive attitude towards adoption of such varieties and their access to them, it seemed to be significant at $5 \%$ level.

In relation to household size, it shows positive relation to adoption. It reveals that probability of adoption of modern variety increases with the household size. It might be due to availability of more agricultural labour which in turn encourages farmers to test now technology. Thus, they tend to try out new technologies expecting higher yield to feed their family members. Average years of schooling were found to be positively and highly significant. All other variables explained in the model showed insignificant effect of MV adoption.

\section{CONCLUSION}

This study explains the impact of community based seed production system on crop productivity and household income. Significant yield gap between adaptors and non-adaptors explains the significant impact of CBSP on rice productivity. It can be stated with greater degree of certainty that commercialization of rice seed production improve the seed security, food security and livelihoods among rice growers in western mid-hill of Nepal. Study also highlights that community based seed production is an efficient system to increase farmers' access to preferred varieties and also to ensure seed security in terms of quality, quantity and timely availability. The analysis showed that, that attendance to agricultural trainings, household income, average age of household head, use of modern varieties, household size, and involvement of women in agricultural decision-making have significant positive effect on the adoption of modern technology.

\section{ACKNOWLEDGEMENT}

Farmers of Sundarbazar VDC of Lamjung and Purkot VDC of Tanahun district who serve as the respondents during household survey are highly acknowledged for their indispensible support on providing valuable information and required data on accomplishment of this research. Leaders of community based seed producers' groups and cooperatives are appreciated for overall coordination from household selection to enumeration. Similarly, I express my sincere thanks to agro-input dealers, local political leaders and VDC authorities and all the enumerators responding keenly to the researcher.

\section{REFERENCES CITED}

CDD. 2011. Ministry of Agriculture Development. Crop Development Directorate. Annual Report 2009/10. Harihar Bhawan, Lalitpur, Nepal.

DISSPRO. 1999. Ministry of Agriculture Development. Department of Agriculture. District Seed Self-Sufficiency Program, Harihar Bhawan, Lalitpur, Nepal.

Manzanilla, D. and David Johnson. 2012. Seeds of Rice in Nepal in Rice Today Jan-March 2012. International Rice Research Institute (IRRI), Philippines. 
MOAD. 2014. Statistical Information on Nepalese Agriculture 2013/2014. Ministry of Agriculture Development. Agri-Business Promotion and Statistics Division (ABPSD), Kathmandu, Nepal.

SQCC. 2012. Ministry of Agriculture Development. Seed Quality Control Center. Annual Progress Report 2010/2011. Harihar Bhawan, Lalitpur, Nepal. 